OPEN ACCESS

Edited by:

Fernando Ariel Genta,

Fundação Oswaldo Cruz (Fiocruz),

Brazil

Reviewed by:

Honoo Satake,

Suntory Foundation for Life Sciences,

Japan

Ulrich Theopold,

Stockholm University, Sweden

*Correspondence:

Kaimin Hui

kaiminhui@hotmail.com

Qian Ren

renqian0402@126.com

tThese authors have contributed

equally to this work.

Specialty section:

This article was submitted to

Invertebrate Physiology,

a section of the journa

Frontiers in Physiology

Received: 16 April 2018 Accepted: 25 June 2018

Published: 16 July 2018

Citation:

Huang Y, Chen Y, Hui K and Ren Q (2018) Cloning and Characterization

of Two Toll Receptors (PcToll5

and PcToll6) in Response to White

Spot Syndrome Virus in the Red

Swamp Crayfish Procambarus clarkii.

Front. Physiol. 9:936.

doi: 10.3389/fphys.2018.00936

\section{Cloning and Characterization of Two Toll Receptors (PcToll5 and PcToll6) in Response to White Spot Syndrome Virus in the Red Swamp Crayfish Procambarus clarkii}

\author{
Ying Huang ${ }^{2 t}$, Yihong Chen ${ }^{4 t}$, Kaimin Hui ${ }^{1 *}$ and Qian Ren ${ }^{1,3 *}$ \\ ${ }^{1}$ College of Marine Science and Engineering, Nanjing Normal University, Nanjing, China, ${ }^{2}$ College of Oceanography, Hohai \\ University, Nanjing, China, ${ }^{3}$ Co-Innovation Center for Marine Bio-Industry Technology of Jiangsu Province, Lianyungang, \\ China, ${ }^{4}$ Guangdong Provincial Key Laboratory of Marine Resources and Coastal Engineering, South China Sea \\ Bio-Resource Exploitation and Protection Collaborative Innovation Center, School of Marine Sciences, Sun Yat-sen \\ University, Guangzhou, China
}

Toll/Toll-like receptors are key components in the innate immune responses of invertebrates. In this study, we identified two novel Toll receptors (PcTol/5 and PcTol/6) from the red swamp crayfish Procambarus clarkii. The complete cDNA sequence of PcToll5 is 4247 bp, encoding a 1293 amino acid polypeptide. The full-length 4688 bp PcToll6 encodes a putative protein of 1195 amino acids. Quantitative RT-PCR analysis indicated that PCToll5 and PCToll6 were constitutively expressed in all tissues studied. The highest expression levels of PcToll5 and PcToll6 were found in the intestine and gills, respectively, and were significantly upregulated from 24 to $48 \mathrm{~h}$ during white spot syndrome virus (WSSV) challenge. siRNA-mediated RNA interference results showed that PCTO/l5 and PCTol/6 might regulate the expression of anti-lipopolysaccharide factors (PCALF2 and PCALF3) in vivo. Overexpression of PcToll5 and PcToll6 in Drosophila Schneider 2 (S2) cells activated the transcription of Drosophila antimicrobial peptides, including drosomycin (Drs), metchnikowin (Mtk), and attacin A (AttA), and shrimp Penaeidin-4 (Pen4). These findings provide significant information that PcToll5 and PCToll6 may contribute to host immune defense against WSSV in P. clarkii.

Keywords: Procambarus clarkii, WSSV, Toll receptors, innate immunity, over-expression, RNAi

\section{INTRODUCTION}

The red swamp crayfish Procambarus clarkii is one of the most important farmed freshwater crayfish species worldwide. However, the sustainable culture of crayfish in China has been hindered by disease outbreaks caused by white spot syndrome virus (WSSV) (Maeda et al., 2000). White spot syndrome (WSS) caused by WSSV is the common destructive virus-induced disease (Arts et al., 2007). Similar to other invertebrates, giant freshwater prawns lack an acquired immune system and relies mainly on their innate immunity to fight against invading foreign microbes (Medzhitov and Janeway, 2000a,b). Therefore, the innate immunity of this species in response to pathogen invasion should be studied (Buchmann, 2014). 
The innate immune system constitutes the first barrier of defense against pathogen invasion in crustaceans and has been conserved throughout the evolutionary process. Upon infection, host germ line-encoded pattern-recognition receptors (PRRs) identify and bind to pathogen-associated molecular patterns (PAMPs) located on the surfaces of microorganisms to trigger multiple downstream signaling pathways (Janeway and Medzhitov, 2002; Medzhitov and Janeway, 2002; Huang et al., 2013). Scholars have studied several PRRs, such as Toll or Tolllike receptors (TLRs), RIG-like receptors, NOD-like receptors, and C-type lectins (Christophides et al., 2004; Huang et al., 2018). Diverse PRRs react with specific PAMPs, exhibit different expression patterns, activate specific signal pathways, and lead to different anti-pathogen responses (Akira et al., 2006).

As one of the most widely studied PRRs, TLRs are involved in pathogen recognition and activation of immune responses (Uematsu and Akira, 2006; Medzhitov, 2007). The first Toll from Drosophila melanogaster is a necessary gene product for embryonic dorsoventral polarity development (Leulier and Lemaitre, 2008; Valanne et al., 2011). This Toll also sense microbial pathogens, such as mammalian TLRs (Lemaitre et al., 1996; Akira et al., 2006). To date, studies have identified 1 Toll-like protein in Caenorhabditis elegans (Tenor and Aballay, 2008), 9 Toll proteins in Drosophila (Valanne et al., 2011), and 10-12 TLRs in mammals (Roach et al., 2005; Akira et al., 2006). A large number of Toll proteins from crustaceans have been widely investigated. In shrimp, Tolls have been studied in Fenneropenaeus chinensis, Penaeus monodon, Marsupenaeus japonicus, Litopenaeus vannamei, and P. clarkii (Arts et al., 2007; Yang et al., 2008; Mekata et al., 2008; Wang et al., 2012, 2015). In the giant tiger shrimp P. monodon, a Toll homolog was expressed in the intestine, gills, and hepatopancreas and could be involved in defense against pathogens (Arts et al., 2007). A Toll receptor from the Chinese shrimp F. chinensis was also expressed in different tissues; the expression was the highest in the lymphoid organ and regulated after Vibrio anguillarum or WSSV stimulation (Yang et al., 2008). A new type of Toll receptor gene was found to be expressed by 76-fold higher than that the control stimulated with peptidoglycan at $12 \mathrm{~h}$ in the lymphoid organ of the kuruma shrimp Marsupenaeus japonicus (Mekata et al., 2008). Three different Tolls (Toll1-3) have been studied in the white leg shrimp L. vannamei based on their protein similarities; all these Tolls met the challenges with Vibrio alginolyticus or WSSV (Wang et al., 2012). In the freshwater crayfish P. clarkii, PcToll was upregulated in different tissues after challenge with $V$. anguillarum or Staphylococcus aureus and was found to be involved in regulation of the expression of antimicrobial peptides (AMPs), including crustins (Cru1 and Cru2), anti-lipopolysaccharide factor 2 (ALF2), and lysozyme 1 (Lys1) (Wang et al., 2015). Silencing P. clarkii Toll (PcToll3) influenced the expression of myeloid differentiation factor 88 (PcMyd88), tumor necrosis factor-associated factor 6 (PcTRAF6), and PcDorsal, which were the counterparts of the Drosophila Toll signaling pathway (Lan et al., 2016). In crabs, Toll reporters were identified in three crab species, one in Scylla paramamosain (Lin et al., 2012), two in Eriocheir sinensis (Yu et al., 2013), and three in Portunus trituberculatus
(Zhou et al., 2015); these reporters were responsive to bacterial pathogens or PAMPs.

In this study, the complete cDNA sequences of two novel Tolls (PcToll5 and PcToll6) from P. clarkii were identified and their responses to WSSV challenge were investigated. This research will be potentially helpful in understanding the innate immune defense of economically important crayfish.

\section{MATERIALS AND METHODS}

\section{WSSV Challenge and Tissue Collection}

One hundred healthy red swamp crayfish (about 15 g each) were obtained from an agricultural market in Nanjing (Jiangsu Province, China). They were acclimated in fresh water in laboratory tanks at $25^{\circ} \mathrm{C}$ for a week before the experiments. Hemolymph was collected from at least five crayfish, mixed with $1 / 3$ volume of anticoagulant buffer (10\% sodium citrate, $\mathrm{pH}$ 7.0) containing $200 \mathrm{mM}$ phenylthiourea, and centrifuged at $800 \mathrm{~g}$ at $4^{\circ} \mathrm{C}$ for $10 \mathrm{~min}$ to isolate hemocytes. Five tissues including heart, hepatopancreas, gill, stomach, and intestine were quickly collected. For the viral challenge experiments, crayfish were divided into two groups (20 crayfish in each group). Each crayfish in group 1 was challenged with $100 \mu \mathrm{l}$ of WSSV $\left(10^{5}\right.$ copies $\left./ \mathrm{mL}\right)$. Each crayfish in group 2 was injected with $100 \mu \mathrm{l}$ of PBS and used as blank control (Huang Y. et al., 2016). At $0,24,36$, and $48 \mathrm{~h}$ post injection (hpi), the intestines were randomly extracted from five crayfish of each group.

\section{Total RNA Extraction and First-Strand cDNA Synthesis}

Total RNA samples from different tissues and the intestine of WSSV-challenged crayfish were extracted in accordance with the manufacturer's instructions (Spin-column, BioTeke, Beijing, China). The $5^{\prime}$ and $3^{\prime}$ cDNA sequences for the rapid amplification of cDNA ends (RACE) were synthesized using the intestine total RNA as template to obtain the full lengths of PcToll5 and PcToll6 genes. First-strand cDNA (5' cDNA and $3^{\prime}$ cDNA) was synthesized using $5^{\prime}$-CDS primer A $\left(5^{\prime}-\mathrm{T}_{25} \mathrm{VN}-3^{\prime}\right)$, SMARTer IIA oligo (5'-AAGCAGTGGTAT CAACGCAGAGTACXXXXX-3'), $3^{\prime}$-CDS primer [5'-AAGCA GTGGTATCAACGCAGAGTAC(T)30VN-3'], and a Clontech SMARTer $^{\text {TM }}$ RACE cDNA Amplification kit from Takara (Dalian, China). First-strand cDNA synthesis of different samples for $\mathrm{qRT}$-PCR analysis was performed using the PrimeScript ${ }^{\circledR}$ First-strand cDNA Synthesis Kit (Takara, Dalian, China) with the Oligo dT Primer (Ren et al., 2014).

\section{cDNA Cloning of PcTol/5 and PcTol/6}

Two expressed sequence tags (ESTs) in P. clarkii similar to TLR genes were obtained from our previous high-throughput transcriptome data. On the basis of the original EST sequences, the following gene-specific primers were designed to clone the full-length cDNAs of PcToll5 and PcToll6, respectively: (PcToll5F: 5'-CGCCTGTGAGGTGTGACCACTATGT-3', PcToll5-R: 5' ACATCCAGAACCACCAGGCGAATAAGC-3'; and PcToll6-F: 
5'-GTGTCGTTTTGAGTTCCGTTCCGCCC-3', PcToll6-R: 5' ACCAATCGGTGTTGTAGGTCCGCAGC-3'). The Advantage 2 PCR Kit from Takara (Dalian, China) was used for gene cloning. The PCR amplification conditions were as follows: five cycles at $94^{\circ} \mathrm{C}$ for $30 \mathrm{~s}$ and $72^{\circ} \mathrm{C}$ for $3 \mathrm{~min}$; five cycles at $94^{\circ} \mathrm{C}$ for $30 \mathrm{~s}, 70^{\circ} \mathrm{C}$ for $30 \mathrm{~s}$, and $72^{\circ} \mathrm{C}$ for $3 \mathrm{~min}$; and 20 cycles at $94^{\circ} \mathrm{C}$ for $30 \mathrm{~s}, 68^{\circ} \mathrm{C}$ for $30 \mathrm{~s}$, and $72^{\circ} \mathrm{C}$ for $3 \mathrm{~min}$ (Huang Y. et al., 2016). The PCR products were cloned into the PEASY ${ }^{\circledR}$-T1 vector (TransGen Biotech) and sequenced (Invitrogen).

\section{Bioinformatics Analysis}

Online BLAST program ${ }^{1}$ was used to search the homology comparisons of nucleotide and amino acid sequences. cDNA translation, pI analysis, and molecular mass prediction were performed by ExPASy. ${ }^{2}$ Domain and signal peptide predictions were conducted by SMART $^{3}$. Multiple protein sequence alignment was performed using MEGA 5.05 and analyzed on GENEDOC software. MEGA 5.05 was utilized to produce phylogenetic trees, and NJ (Neighbor-Joining) method was applied to phylogenetic analysis (Kumar et al., 2008).

\section{Quantitative Real-Time PCR (qRT-PCR)}

Tissue distribution and expression profiles of PcToll5 and PcToll6 were analyzed by qRT-PCR with the prepared cDNA. PcToll5 and PcToll6 were amplified with specific primers (PcToll5-RT-F: 5'-GCAAACCGCATCAAAGCGACCA-3' and PcToll5-RT-R: 5' GCAGCAGCAAGCAGCAGCAACA-3'; PcToll6-RT-F: 5'-GCC TTCGCTGTTCTCCTCACC-3' and PcToll6-RT-R: 5'-TCCCC TTCATACTCGCTCCTG-3'), respectively. The procedure of qRT-PCR consisted of the following: $95^{\circ} \mathrm{C}$ for $30 \mathrm{~s}$, followed by 40 cycles of $95^{\circ} \mathrm{C}$ for $5 \mathrm{~s}$, and $60^{\circ} \mathrm{C}$ for $30 \mathrm{~s}$. Melting curve analysis was conducted to confirm the specificity of qRTPCR amplification. Glyceraldehyde 3-phosphate dehydrogenase (GAPDH) was also amplified for internal standardization with the corresponding primers (PcGAPDH-RT-F: 5'-CAATGTTC GTCTGTGGAGTGA- $3^{\prime}$ and PcGAPDH-RT-R: 5'-GGAAGAT $^{\prime}$ GGGATGATGTTCTG-3'). Comparative threshold cycle method $\left(2^{-\Delta \Delta \mathrm{CT}}\right)$ was used to calculate the transcript expression levels (Livak and Schmittgen, 2001). The experiment was repeated three times.

\section{Dual Luciferase Activity Assay in S2 Cells}

The expression vector for the full-length PcToll5 or PcToll6 was constructed using pAc5.1/V5-His B (Invitrogen, United States). The PCR products were amplified with the specific primers (PcToll5-pAc-F: 5' -CCCGGATCGGGGTACCATGCTCAGCCG CTTGGAGGCCCTTG-3' and PcToll5-pAc-R: 5' -TTCGAACCG CGGGCCCTCTAAAGACGGCATTGCTCTGCGT-3'; PcToll6pAc-F: 5'-CCCGGATCGGGGTACCATGCTCCAGGATGTGAC AGTTCTG-3', and PcToll6-pAc-R: 5'-TTCGAACCGCGGGC CCTCAGTGTCGCCCCATTTAAGATAGG-3'). After digestion with Kpn I and Apa I (Takara, Dalian, China), the PCR products

\footnotetext{
${ }^{1}$ https://blast.ncbi.nlm.nih.gov/Blast.cgi

${ }^{2}$ http://www.expasy.ch/

${ }^{3} \mathrm{http}: / /$ smart.embl-heidelberg.de/
}

were cloned into pAc5.1/V5-His B. The positive clones were sequenced to ensure correct insertion. On account of the unavailability of a crayfish cell line, Drosophila Schneider 2 (S2) cells (Invitrogen, United States) were used to explore the activation of AMP transcription of PcToll5 and PcToll6. S2 cells were cultured in Drosophila serum-free medium SDM (Invitrogen, United States) augmented with 10\% fetal bovine serum (Invitrogen) at $27^{\circ} \mathrm{C}$. The cells were seeded overnight for DNA transfection, and the plasmids were transfected using the Cellfectin II reagent (Invitrogen). Dual-luciferase reporter assays were carried out by transfecting S2 cells in 96-well plates (TPP, Switzerland) by using $0.3 \mathrm{~g}$ of expression plasmids, $0.2 \mathrm{~g}$ of reporter gene plasmids, and $0.02 \mathrm{~g}$ of pRL-TK renilla luciferase plasmid (Promega, United States) as control. The reporter gene plasmids were constructed using the promoter sequences of the following genes: L. vannamei AMP penaeidin-4 (Pen4), Drosophila AMPs, metchnikowin (Mtk), drosomycin (Drs), and attacin A (AttA). All the assays were performed in triplicate. At $48 \mathrm{~h}$ post-transfection, firefly and renilla luciferase activities were measured on the Dual-Luciferase Reporter Assay System (Promega, United States) (Huang et al., 2015).

\section{siRNA-Mediated RNA Interference Assay and Expression Patterns of ALFs}

Based on the sequences of PcToll5 and PcToll6 genes, siRNAs specifically targeting PcToll5 and PcToll6 were synthesized in vitro by using a commercial kit (Takara, Japan) according to the manufacturer's instructions. The siRNAs used were as follows: PcToll5-siRNA (5'-GCACCGAAACAUUCUCAUA-3') and PcToll6-siRNA (5'-GCUCUUCUUUCAAAGUGCACUUCAA$\left.3^{\prime}\right)$. The sequences of the siRNAs were scrambled to generate the following: control PcToll5-siRNA-scrambled (5'-ACGCAA GACAUCUAUACCU-3') and PcToll6-siRNA-scrambled (5'-GU CUUACUCUCAUGCAUAGUUCACA- $3^{\prime}$ ). The synthesized siRNAs were dissolved in siRNA buffer and quantified by spectrophotometry (Huang et al., 2014).

Healthy crayfish were assigned to five groups. Crayfish in group 1 or 2 were injected with $20 \mu \mathrm{g}$ of PcToll5-siRNA or PcToll6-siRNA, respectively. At $16 \mathrm{~h}$ after the injection, PcToll5-siRNA or PcToll6-siRNA $(20 \mu \mathrm{g})$ with WSSV $\left(10^{5}\right.$ copies $/ \mathrm{mL}) \quad(100 \mu \mathrm{l} /$ crayfish $)$ were injected into the same crayfish. Crayfish in groups 3 or 4 were initially injected with $20 \mu \mathrm{g}$ of PcToll5-siRNA-scrambled or PcToll6-siRNAscrambled, respectively. After 16 h, $20 \mu \mathrm{g}$ of PcToll5-siRNAscrambled or PcToll6-siRNA-scrambled and WSSV was injected into the same crayfish. At $36 \mathrm{~h}$ after the last injection, the intestine was isolated from five crayfish for RNA extraction and first-strand cDNA synthesis. qRT-PCR analysis was conducted to determine the efficiency of RNAi. After RNAi assay, the expression levels of ALF genes were determined through qRTPCR analysis. The gene expression levels of PCALF2 and PCALF3 were analyzed in the intestine. The primers used were PcALF2RT-F: 5'-CGTGGGAGTGTTTGTGGTGGT-3' and PcALF2-RTR: 5'-TTGGaCTGTAACTGTAGCGGC-3'; PcALF3-RT-F: 5' AGGTGTTGAaGATGAAGTGGT-3' and PcALF3-RT-R: 5' $^{\prime}$ GCTTGTTGATAATGAGGGTGA-3' 


\section{RESULTS}

\section{Identification of PcToll5 and PcToll6 in P. clarkii}

The full length of PcToll5 (KU680804) is $4247 \mathrm{bp}$, which includes a $5^{\prime}$ untranslated region (UTR) of $159 \mathrm{bp}$, a $3882 \mathrm{bp}$ open reading frame (ORF) encoding a protein of 1293 amino acids (aa), and a $3^{\prime}$ untranslated region of 206 bp (Supplementary Figure S1A). The PcToll5 protein contains of 16 leucine-rich repeat (LRR) domains with an aa length of 16-26, 7 LRR domains of 24 aa (belonging to the most populated subfamily LRR TYP), 2 LRR C-terminal (LRR CT) domains of 60 and 53 aa, an LRR $\mathrm{N}$-terminal domain (LRR NT) domain of $38 \mathrm{aa}$, a transmembrane domain of 23 aa, and an intracellular Toll/interleukin-1 (IL1) receptor (TIR) domain of 140 aa (Figure 1). The molecular weight (MW) and predicted isoelectric point (pI) of PcToll5 are $143.2 \mathrm{kDa}$ and 6.43 , respectively. The complete cDNA sequence of PcToll6 (KU680807) is 4688 bp, which includes a 308 bp $5^{\prime}$ UTR, a 3588 bp ORF encoding an 1195 amino acid polypeptide, and a 792 bp 3'UTR (Supplementary Figure S1B). The PcToll6 protein contains a signal peptide of 18 aa, 19 LRR domains with an aa length of 20 to 30, 6 LRR TYP domains of 24 aa, 2 LRR CT domains of 57 and 53 aa, an LRR NT domain of 39 aa, a transmembrane domain of 23 aa, and a TIR domain of 138 aa (Figure 1). PcToll6 has a MW of $136.4 \mathrm{kDa}$ and a $\mathrm{pI}$ of 5.70 .

\section{Sequence Analysis of PcToll5 and PcToll6}

Multiple alignments at the amino acid level showed that PcToll5 and PcToll6 were highly conserved with each other (Supplementary Figure S2). BLASTX result showed that PcToll5 shared 53\% identity with Toll from Parhyale hawaiensis and $41 \%$ identity with Tolls from Pediculus humanus corporis, Athalia rosae, Cephus cinctus, and Fopius arisanus. PcToll6 shared $87 \%$ identity with Toll from P. trituberculatus, 67\% identity with Toll from $P$. hawaiensis, and 54\% identity with Tolls from P. humanus corporis, Nilaparvata lugens, Tribolium castaneum, and Zootermopsis nevadensis. Phylogenetic analysis of the reported crustacean Toll proteins demonstrated that PcToll5 and PcToll6 were clustered together with $P$. trituberculatus Toll1, Macrobrachium rosenbergii Toll3, P. clarkii Toll3, and L. vannamei Toll3 (Figure 2).

\section{Tissue Distribution and Expression Profiles of PcToll5 and PcToll6}

PcToll5 and PcToll6 were expressed in all tissues studied. The highest expression levels of PcToll5 and PcToll6 were found in the intestine and gills, respectively (Figure 3). The expression profiles of PcToll5 and PcToll6 in the intestine or gills were further examined after WSSV challenge. PcToll5 and PcToll6 cDNAs were significantly upregulated in different tissues after challenge with WSSV but showed no significant change in their expression in the PBS-treated group (Figure 4). The highest expression of PcToll5 after challenge with WSSV in the intestine and gills was found at 36 and $48 \mathrm{~h}$ post injection, respectively. The PcToll6 expression reached the highest level at $36 \mathrm{~h}$ in the intestine and gills. Hence, PcToll5 and PcToll6 might be involved in anti-WSSV immune responses.

\section{Overexpression of PcToll5 and PcToll6 in Drosophila S2 Cells}

PcToll5 and PcToll6 significantly activated the promoters of Drosophila or L. vannamei AMP genes (Figure 5). PcToll5 induced the promoter activities of AMP Pen 4 by 4.2 -fold, Mtk by 3.4-fold, Drs by 2.8-fold, and AttA by 5.4-fold. PcToll6 induced the promoter activities of AMP Pen 4 by 2.1 -fold, $M t k$ by 3.4 -fold, Drs by 2.3-fold, and AttA by 3.3-fold.

PcToll5

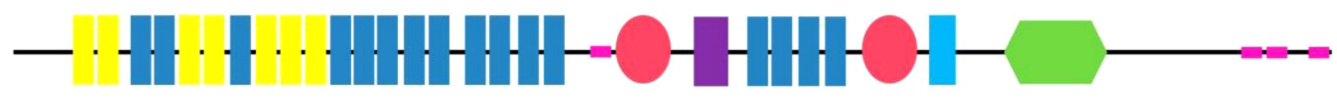

PcToll6

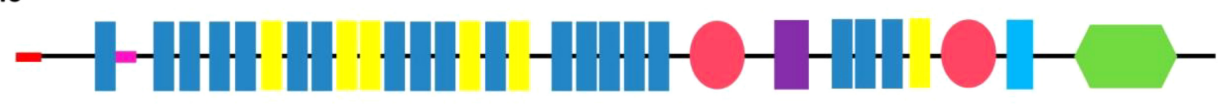

LRR domain

LRR NT domain

- Low complexity region
LRR TYP domain

Transmembrane region

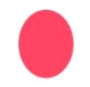

LRR CT domain

TIR domain

FIGURE 1 | Schematic representation of the domain topology of PcToll5 and PcToll6. 


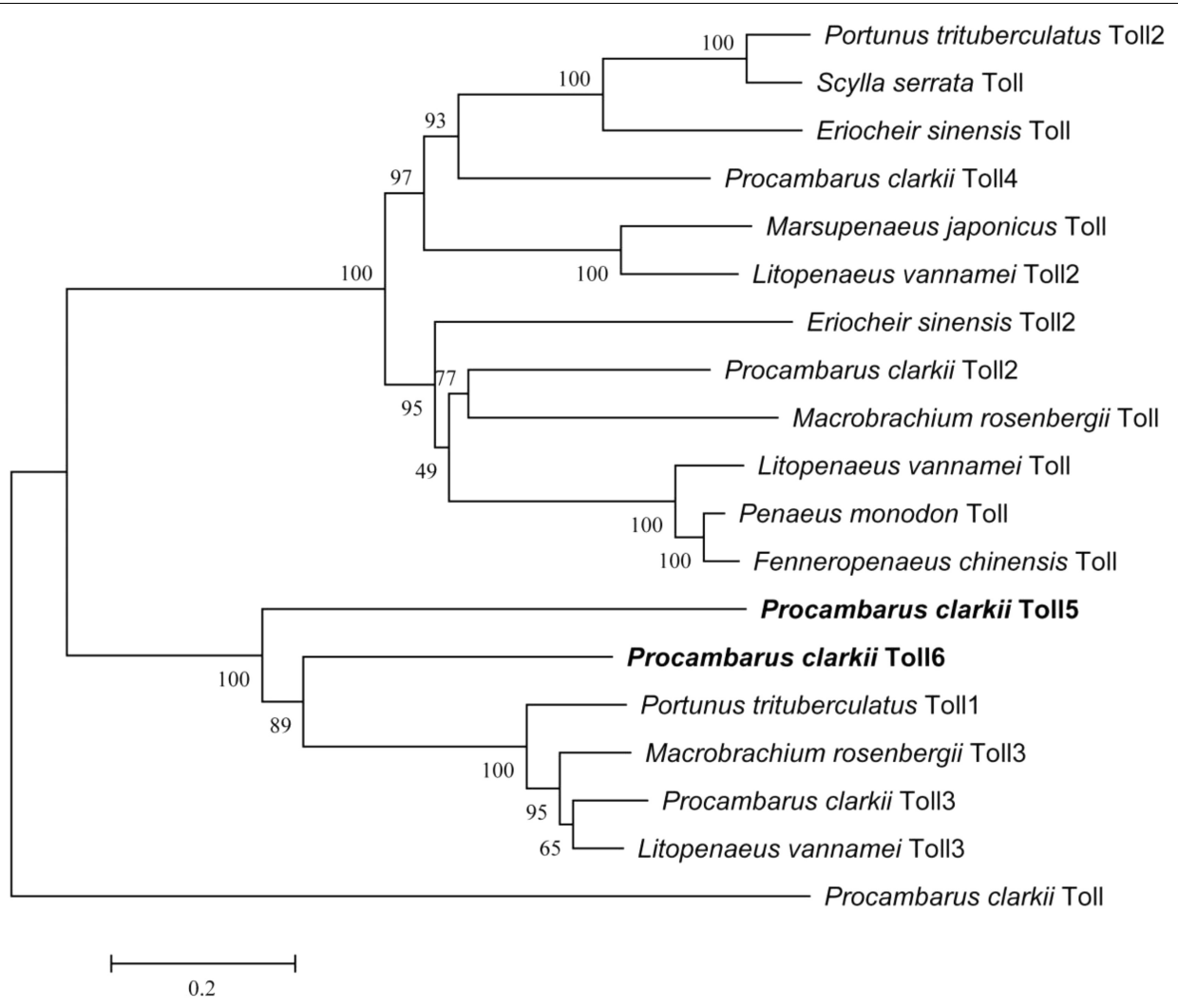

FIGURE 2 | Phylogenetic analysis of PcToll5, PcToll6 and other crustacean Toll proteins. Eriocheir sinensis Toll, Toll2: Accession No. AGK90305.1, AGT21374.1; Fenneropenaeus chinensis Toll: Accession No. ABQ59330.1; L. vannamei Toll, Toll2, Toll3: Accession No. ABK58729.1, AEK86516.1, AEK86517.1; Macrobrachium rosenbergii Toll, Toll3: Accession No. AEl25533.1, AHL39102.1; Marsupenaeus japonicus Toll: Accession No. BAF99007.1; Penaeus monodon Toll: Accession No. ADK55066.1; Portunus trituberculatus Toll1, Toll2: Accession No. AKV62617.1, AlZ66853.1; Scylla serrata Toll: Accession No. AGG55849.1.

A

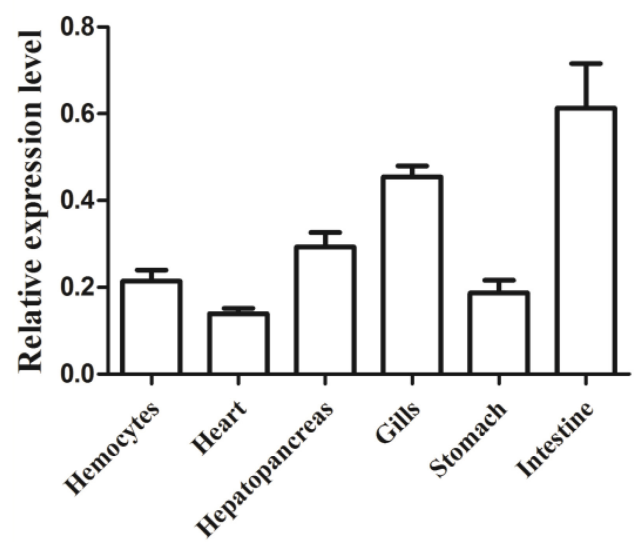

B

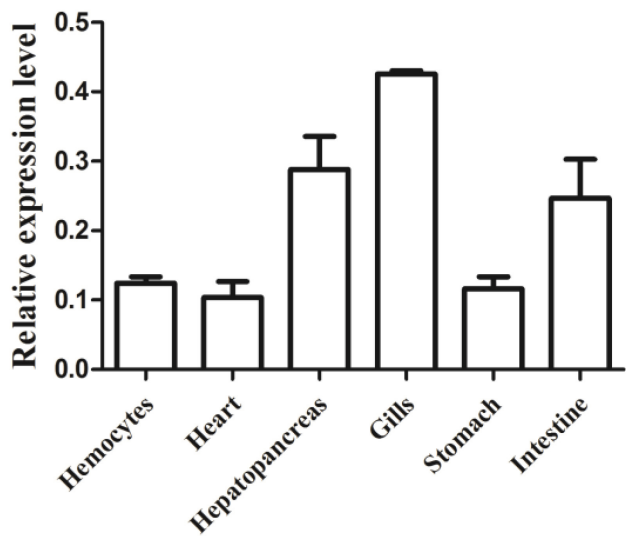

FIGURE 3 | qRT-PCR analysis of PCToll5 (A), and PCTol/6 (B) in the hemocytes, heart, hepatopancreas, gills, stomach and intestine of healthy crayfish. GAPDH was used as an internal control.

\section{PcToll5 and PcToll6 Affect the Transcription of ALFs}

The expression of PcToll5 or PcToll6 in the corresponding siRNA interference group was significantly knocked down in the intestine of $P$. clarkii at $36 \mathrm{~h}$ compared with that in the WSSV group. Control siRNA-scrambled did not affect the gene expression, indicating that Toll-siRNA is highly specific to PcToll5 or PcToll6. When PcToll5 or PcToll6 expression was 

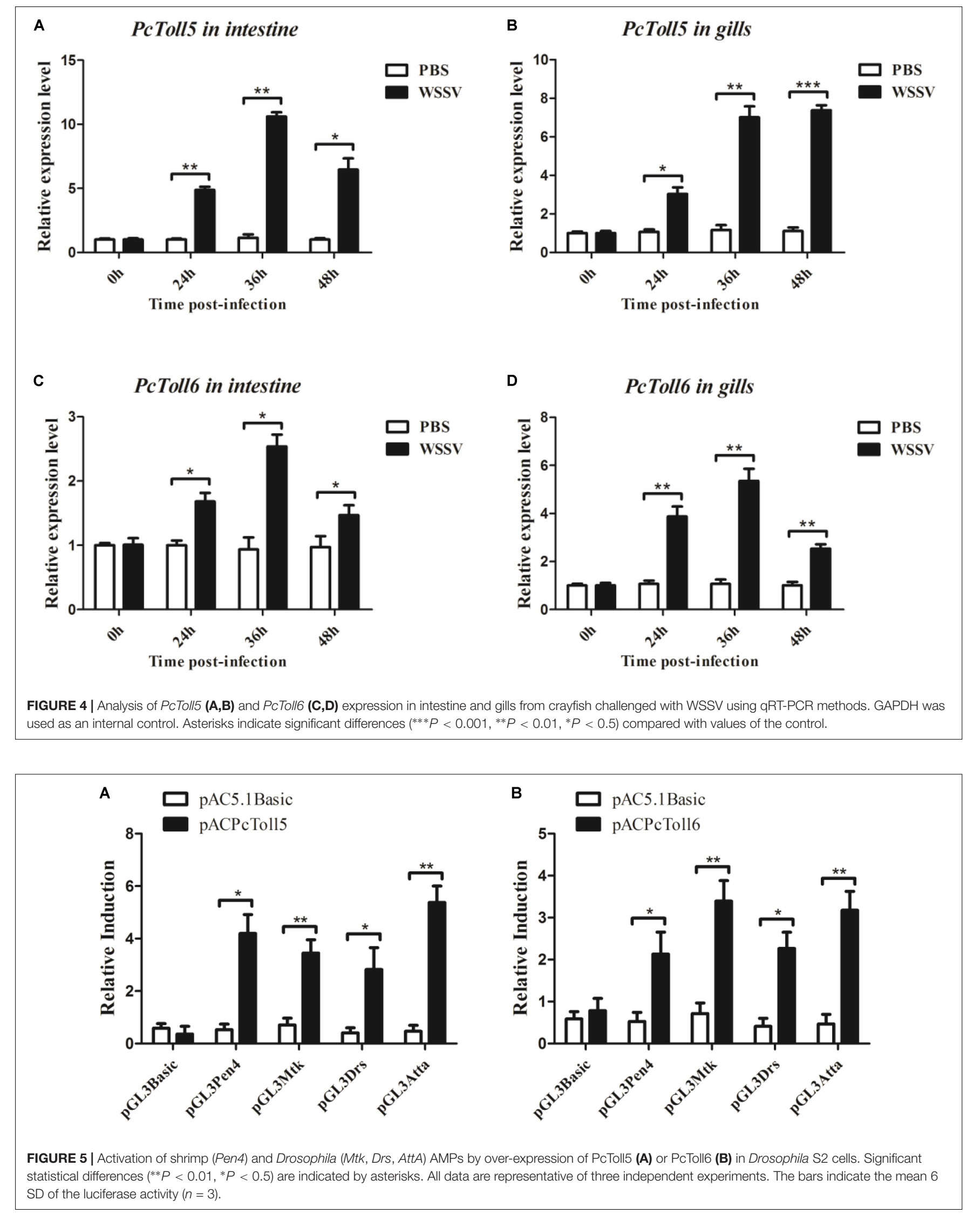


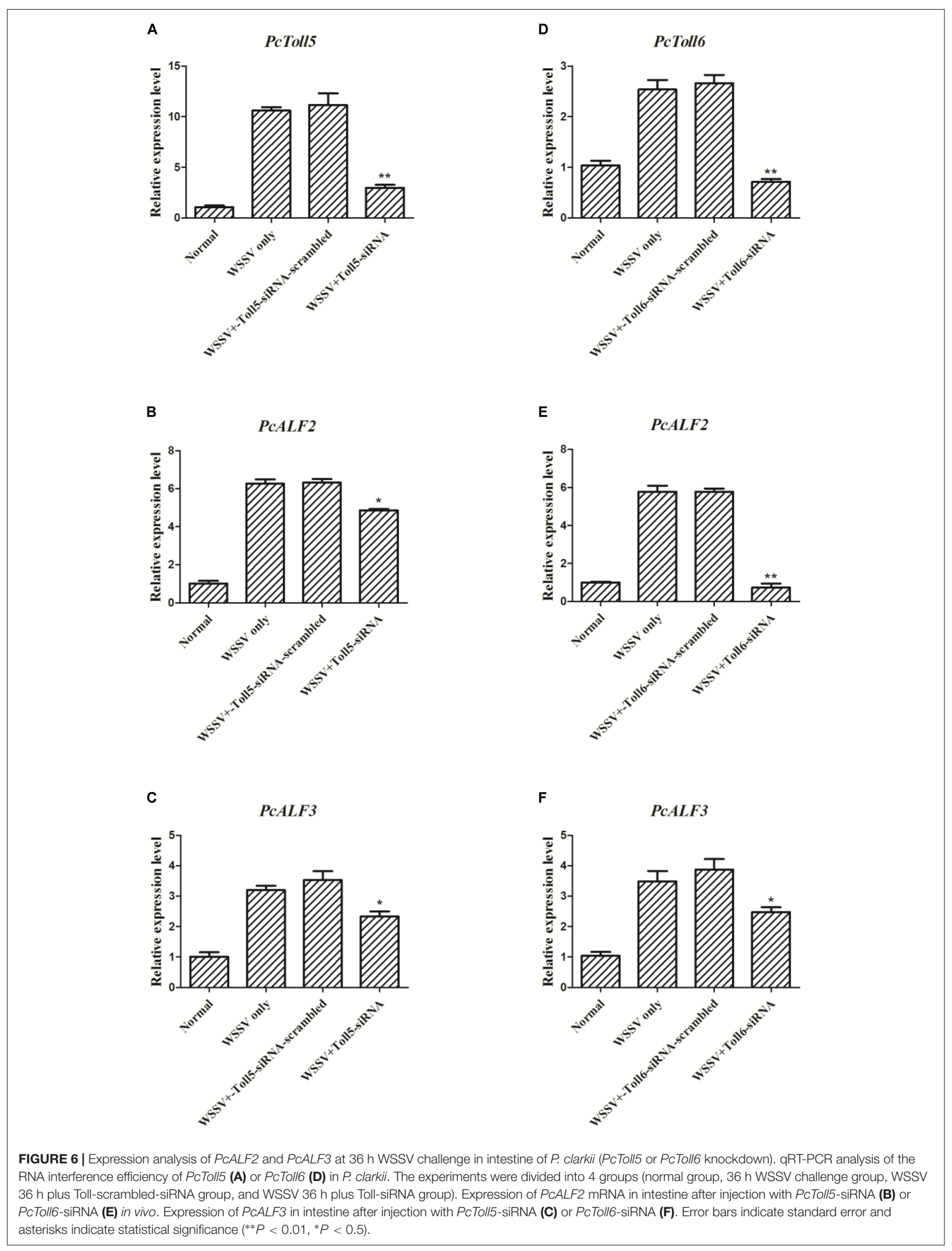


inhibited, the $A L F$ expression was tested through qRT-PCR analysis. As shown in Figure 6, two ALFs (PcALF2 and $P c A L F 3$ ) were significantly upregulated $36 \mathrm{~h}$ after the WSSV challenge. However, knocked down of PcToll5 or PcToll6 inhibited the transcription of these two ALFs.

\section{Expression of PcALF2 and PcALF3 During WSSV Infection}

PCALF2 and PcALF3 genes were characterized, and their expression patterns were determined in the intestine of crayfish to evaluate their roles during WSSV infection. As shown in Figure 7, the mRNAs of PCALF2 and PCALF3 were upregulated after WSSV infection at several time points $(24,36$, and $48 \mathrm{~h})$. By contrast, the expression of ALFs did not obviously change after PBS challenge.

\section{DISCUSSION}

Toll receptors are key components in the innate immune responses of invertebrates. Different types of Tolls have been found in several crustacean species (Arts et al., 2007; Mekata et al., 2008; Yang et al., 2008; Lin et al., 2012; Wang et al., 2012, 2015; Yu et al., 2013; Zhou et al., 2015; Lan et al., 2016; Huang et al., 2017). In our previous work, four Toll receptors (PcToll, PcToll2, PcToll3, and PcToll4) were identified in the red swamp crayfish $P$. clarkii on the basis of sequence similarities and phylogenetic relationships (Wang et al., 2015; Lan et al., 2016; Huang et al., 2017). In the current study, for the first time, two novel Tolls (PcToll5 and PcToll6) were characterized in P. clarkii. Based on the phylogenetic analyses, PcToll5 and PcToll6 exhibited high similarity to crab Toll protein found in P. trituberculatus and shrimp Toll proteins in $M$. rosenbergii, $P$. clarkii, and L. vannamei and clustered on one branch. PcToll5 and PcToll6 contain more than 20 LRR-related motifs, a transmembrane region, and a TIR domain. LRRs are found in more than 2000 proteins from viruses to eukaryotes (Enkhbayar et al., 2004). Most LRRs are composed of 2-45 motifs, which contain 20-30 amino acids in length and provide a structural framework of protein-protein interactions (Kobe and Kajava, 2001; Enkhbayar et al., 2004).
Proteins containing LRRs play a significant role in a number of biological processes, such as signal transduction, DNA repair, cell adhesion, recombination, RNA processing, transcription, disease resistance, apoptosis, and immune response (Rothberg et al., 1990). LRRs are accompanied by cysteine-rich domains: an N-terminal LRR domain and a C-terminal LRR domain. Members of the Toll family are type I transmembrane receptors, which are characterized by an intracellular 200 residue domain with interleukin-1 receptor (IL-1R) and a Toll/IL-1R homologous region (TIR). The TIR domain is essential for Toll proteins and necessary for downstream signal transduction (Kawai and Akira, 2010). This domain is highly conserved not only among different TLRs of one species but also among different animal species (Werling et al., 2009).

PcToll5 and PcToll6 exist in different tissues of crayfish. A high expression of PcToll5 or PcToll6 was observed in the intestine or gills. The intestine provides an active environment for a variety of microbes, including pathogens, because of its digestion and absorption functions (Huang and Ren, 2015). The gills are frequently exposed to the environment because they are relevant for water and air exchange (Huang X. et al., 2016). The different Tolls in L. vannamei were constitutively expressed in all tested tissues (Wang et al., 2012). Tolls identified in three crab species were also widely expressed in few tissues (Lin et al., 2012; Yu et al., 2013; Zhou et al., 2015). Our investigation on the anti-WSSV functions of PcToll5 and PcToll6 showed that WSSV upregulated the expression of PcToll5 and PcToll6 in the intestine or gills after 24, 36, and $48 \mathrm{~h}$ of viral challenge. The FcToll expression in the lymphoid organ of F. chinensis was downregulated at early periods after WSSV challenge (Yang et al., 2008). Hemolytic PcToll3 transcription was upregulated $12 \mathrm{~h}$ after $V$. parahemolyticus injection or $24 \mathrm{~h}$ post WSSV challenge (Lan et al., 2016). WSSV also upregulated the expression of MrToll in the gills of $M$. rosenbergii after 24, 36, and $48 \mathrm{~h}$ of viral challenge (Feng et al., 2016). Another MrToll was enhanced 3-12 h after Aeromonas caviae stimulation and decreased to basal levels at $24 \mathrm{~h}$ post challenge (Srisuk et al., 2014).

Increasing lines of evidence have indicated that the crustacean Toll signaling pathway exerts anti-bacterial, anti-fungal, and
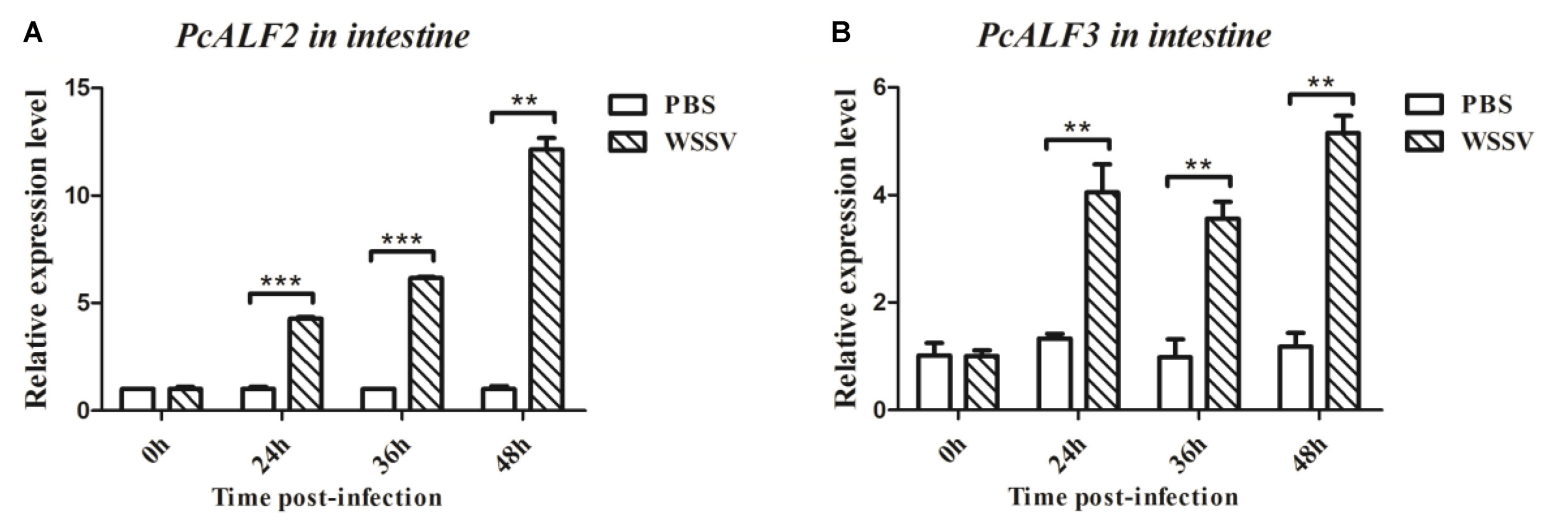

FIGURE 7 | Analysis of PCALF2 (A) and PCALF3 (B) expression in intestine from the crayfish challenged with WSSV using qRT-PCR methods. Asterisks indicate significant differences $\left({ }^{* * *} P<0.001,{ }^{* *} P<0.01\right)$ compared with values of the control. 
anti-viral functions by regulating the expression of immunerelated genes (Wang et al., 2015; Lan et al., 2016; Feng et al., 2016). AMPs are one of the major constituents of the invertebrate innate immune system and function as the front line of host defense against microbial infection (Silva et al., 2013). Crustacean AMPs include several families such as Crus, ALFs, and Lys (Lin et al., 2015). Most research focused on the anti-bacterial function of ALFs, which were reported to be involved in anti-viral defense. Pacifastacus leniusculus ALF interfered with WSSV replication and effectively protected crayfish from WSSV infection (Liu et al., 2006). P. monodon ALFPm 3 exhibited anti-WSSV activity by interacting with the envelope protein WSSV189 and other WSSV structural proteins (Tharntada et al., 2009; Suraprasit et al., 2014). nLvALF1 with its SNP polymorphisms participated in defense against WSSV in L. vannamei (Liu et al., 2014). In the present study, when PcToll5 or PcToll6 was silenced, the expression levels of PCALF2 and PCALF3 were significantly suppressed after WSSV challenge; hence, PCALF2 and PcALF3 might be regulated by the Toll-mediated signaling pathway. In P. clarkii, PcToll was involved in regulation of Cru1, Cru2, ALF2, and Lys1 expression (Wang et al., 2015). PcToll3 silencing influenced the expression of Cru1 and Lys1 after Vibrio challenge (Lan et al., 2016). In the giant freshwater prawn M. rosenbergii, ALF2, ALF3, ALF4, and ALF5 were regulated by MrToll in the gills during WSSV challenge (Feng et al., 2016). In the present work, overexpression of PcToll5 or PcToll6 in Drosophila S2 cells was conducted to determine the roles of PcToll5 and PcToll6 in AMP expression. The results also implied that PcToll5 and PcToll6 activated the transcription of AMPs such as AttA, Mtk, Drs, and Pen4. Based on RNAi and overexpression assay, PcToll5 and PcToll6 played important roles in anti-WSSV immune defense by regulating ALF gene expression.

\section{CONCLUSION}

Two novel Tolls (PcToll5 and PcToll6) from P. clarkii were cloned and characterized. PcToll5 and PcToll6 were broadly expressed in all tested tissues of crayfish, and their transcription was induced by WSSV challenge. Overexpression and RNAi

\section{REFERENCES}

Akira, S., Uematsu, S., and Takeuchi, O. (2006). Pathogen recognition and innate immunity. Cell 124, 783-801.

Arts, J. A., Cornelissen, F. H., Cijsouw, T., Hermsen, T., Savelkoul, H. F., and Stet, R. J. (2007). Molecular cloning and expression of a Toll receptor in the giant tiger shrimp, Penaeus monodon. Fish Shellfish Immunol. 23, 504-513.

Buchmann, K. (2014). Evolution of innate immunity: clues from invertebrates via fish to mammals. Front. Immunol. 5:459. doi: 10.3389/fimmu.2014. 00459

Christophides, G. K., Vlachou, D., and Kafatos, F. C. (2004). Comparative and functional genomics of the innate immune system in the malaria vector Anopheles gambiae. Immunol. Rev. 198, 127-148.

Enkhbayar, P., Kamiya, M., Osaki, M., Matsumoto, T., and Matsushima, N. (2004). Structural principles of leucine-rich repeat (LRR) proteins. Proteins 54, 394-403.

Feng, J., Zhao, L., Jin, M., Li, T., Wu, L., and Chen, Y. (2016). Toll receptor response to white spot syndrome virus challenge in giant freshwater prawns (Macrobrachium rosenbergii). Fish Shellfish Immunol. 57, 148-159. doi: 10.1016/ j.fsi.2016.08.017 experiments showed that PcToll5 and PcToll6 could regulate the expression of AMPs. All these results suggest that PcToll5 and PcToll6 may participate in innate immunity against pathogen infection. However, further studies are required to clarify the specific function and immune mechanism of PcTolls in crayfish immune defense.

\section{ETHICS STATEMENT}

We declare that appropriate ethical approval and licenses were obtained during our research.

\section{AUTHOR CONTRIBUTIONS}

$\mathrm{YH}$ and $\mathrm{YC}$ carried out the experiments, contributed reagents and materials. $\mathrm{YH}, \mathrm{KH}$, and $\mathrm{QR}$ designed the experiments and analyzed the data. $\mathrm{YH}$ and QR wrote the manuscript. All authors gave final approval for publication.

\section{FUNDING}

The current study was supported by the National Natural Science Foundation of China (Grant No. 31702370), the Fundamental Research Funds for the Central Universities (2018B03214), the Natural Science Foundation of Jiangsu Province (BK20171474), Natural Science Fund of Colleges and Universities in Jiangsu Province (16KJD240001), and the Project Funded by the Priority Academic Program Development of Jiangsu Higher Education Institutions (PAPD).

\section{SUPPLEMENTARY MATERIAL}

The Supplementary Material for this article can be found online at: https://www.frontiersin.org/articles/10.3389/fphys. 2018.00936/full\#supplementary-material

Huang, X., Li, W., Jin, M., Ma, F. T., Huang, Y., and Shi, Y. R. (2016). Single CRD containing lectin from Macrobrachium rosenbergii (MrLec) participates in innate immunity against pathogen infections. Fish Shellfish Immunol. 51, 282-290. doi: 10.1016/j.fsi.2016.01.043

Huang, Y., An, L., Hui, K. M., Ren, Q., and Wang, W. (2013). An LDLa domaincontaining C-type lectin is involved in the innate immunity of Eriocheir sinensis. Dev. Comp. Immunol. 42, 333-344. doi: 10.1016/j.dci.2013.10.004

Huang, Y., Chen, Y. H., Wang, Z., Wang, W., and Ren, Q. (2014). Novel myeloid differentiation factor 88, EsMyD88, exhibits EsTube-binding activity in Chinese mitten crab Eriocheir sinensis. Dev. Comp. Immunol. 47, 298-308. doi: 10.1016/ j.dci.2014.08.005

Huang, Y., Chen, Y. H., Zhang, Y. Z., Feng, J. L., Zhao, L. L., Zhu, H. X., et al. (2015). Identification, characterization, and functional studies of a Pelle gene in the Chinese mitten crab, Eriocheir sinensis. Fish Shellfish Immunol. 45, 704-716. doi: 10.1016/j.fsi.2015.05.027

Huang, Y., Han, K., and Ren, Q. (2018). Cloning and analysis of gene expression of two toll receptors in freshwater pearl mussel Hyriopsis cumingii. Front. Physiol. 9:133. doi: 10.3389/fphys.2018.00133

Huang, Y., Jin, M., Yin, S. W., Ding, Z. F., Wang, W., and Ren, Q. (2016). Responses of three very large inducible GTPases to bacterial and white spot syndrome 
virus challenges in the giant fresh water prawn Macrobrachium rosenbergii. Fish Shellfish Immunol. 51, 77-96. doi: 10.1016/j.fsi.2016.01.037

Huang, Y., Li, T. T., Jin, M., Yin, S. W., Hui, K. M., and Ren, Q. (2017). Newly identified PcToll4 regulates antimicrobial peptide expression in intestine of red swamp crayfish Procambarus clarkii. Gene 610, 140-147. doi: 10.1016/j.gene. 2017.02.018

Huang, Y., and Ren, Q. (2015). Identification and function of 11 Rab GTPases in giant freshwater prawn Macrobrachium rosenbergii. Fish Shellfish Immunol. 43, 120-130. doi: 10.1016/j.fsi.2014.12.021

Janeway, C. A. Jr., and Medzhitov, R. (2002). Innate immune recognition. Annu. Rev. Immunol. 20, 197-216.

Kawai, T., and Akira, S. (2010). The role of pattern-recognition receptors in innate immunity: update on Toll-like receptors. Nat. Immunol. 11, 373-384. doi: $10.1038 /$ ni.1863

Kobe, B., and Kajava, A. V. (2001). The leucine-rich repeat as a protein recognition motif. Curr. Opin. Struct. Biol. 11, 725-732.

Kumar, S., Nei, M., Dudley, J., and Tamura, K. (2008). MEGA: a biologistcentric software for evolutionary analysis of DNA and protein sequences. Brief. Bioinform. 9, 299-306. doi: 10.1093/bib/bbn017

Lan, J. F., Wei, S., Wang, Y. Q., Dai, Y. J., Tu, J. G., and Zhao, L. J. (2016). PcToll3 was involved in anti-Vibrio response by regulating the expression of antimicrobial peptides in red swamp crayfish, Procambarus clarkii. Fish Shellfish Immunol. 57, 17-24. doi: 10.1016/j.fsi.2016.08.021

Lemaitre, B., Nicolas, E., Michaut, L., Reichhart, J. M., and Hoffmann, J. A. (1996). The dorsoventral regulatory gene cassette spatzle/Toll/cactus controls the potent antifungal response in Drosophila adults. Cell 86, 973-983.

Leulier, F., and Lemaitre, B. (2008). Toll-like receptors-taking an evolutionary approach. Nat. Rev. Genet. 9, 165-178. doi: 10.1038/nrg2303

Lin, X. Y., Bi, Y. H., and Han, J. Q. (2015). Antimicrobial proteins: from old proteins, new tricks. Mol. Immunol. 68, 383-398. doi: 10.1016/j.molimm.2015. 08.009

Lin, Z., Qiao, J., Zhang, Y., Guo, L., Huang, H., and Yan, F. (2012). Cloning and characterization of the SpToll gene from green mud crab, Scylla paramamosain. Dev. Comp. Immunol. 37, 164-175. doi: 10.1016/j.dci.2011.09.003

Liu, H., Jiravanichpaisal, P., Söderhöll, I., Cerenius, L., and Söderhöll, K. (2006). Antilipopolysaccharide factor interferes with white spot syndrome virus replication in vitro and in vivo in the crayfish Pacifastacus leniusculus. J. Virol. 80, 10365-10371.

Liu, J., Yu, Y., Li, F., Zhang, X., and Xiang, J. (2014). A new anti-lipopolysaccharide factor (ALF) gene with its SNP polymorphisms related to WSSV-resistance of Litopenaeus vannamei. Fish Shellfish Immunol. 39, 24-33. doi: 10.1016/j.fsi. 2014.04.009

Livak, K. J., and Schmittgen, T. D. (2001). Analysis of relative gene expression data using real-time quantitative PCR and the $2(-\Delta \Delta \mathrm{C}(\mathrm{T})$ method. Methods 25, 402-408.

Maeda, M., Itami, T., Mizuki, E., Tanaka, R., Yoshizu, Y., and Doi, K. (2000). Red swamp crawfish (Procambarus clarkii): an alternative experimental host in the study of white spot syndrome virus. Acta Virol. 44, 371-374.

Medzhitov, R. (2007). TLR-mediated innate immune recognition. Semin. Immunol. $19,1-2$.

Medzhitov, R., and Janeway, C. A. Jr. (2000a). Innate immune recognition: mechanisms and pathways. Immunol. Rev. 173, 89-97.

Medzhitov, R., and Janeway, C. A. Jr. (2000b). Innate immunity. N. Engl. J. Med. $343,338-344$.

Medzhitov, R., and Janeway, C. A. Jr. (2002). Decoding the patterns of self and nonself by the innate immune system. Science 296, 298-300.

Mekata, T., Kono, T., Yoshida, T., Sakai, M., and Itami, T. (2008). Identification of cDNA encoding Toll receptor, MjToll gene from kuruma shrimp, Marsupenaeus japonicus. Fish Shellfish Immunol. 24, 122-133. doi: 10.1016/j.fsi.2007. 10.006

Ren, Q., Chen, Y. H., Ding, Z. F., Huang, Y., and Shi, Y. R. (2014). Identification and function of two myeloid differentiation factor 88 variants in triangleshell pearl mussel (Hyriopsis cumingii). Dev. Comp. Immunol. 42, 286-293. doi: $10.1016 /$ j.dci.2013.09.012
Roach, J. C., Glusman, G., Rowen, L., Kaur, A., Purcell, M. K., and Smith, K. D. (2005). The evolution of vertebrate Toll-like receptors. Proc. Natl. Acad. Sci. U.S.A. 102, 9577-9582.

Rothberg, J. M., Jacobs, J. R., Goodman, C. S., and Artavanis-Tsakonas, S. (1990). slit: an extracellular protein necessary for development of midline glia and commissural axon pathways contains both EGF and LRR domains. Genes Dev. 4, 2169-2187.

Silva, N. C., Sarmento, B., and Pintado, M. (2013). The importance of antimicrobial peptides and their potential for therapeutic use in ophthalmology. Int. J. Antimicrob. Agents 41, 5-10. doi: 10.1016/j.ijantimicag.2012.07.020

Srisuk, C., Longyant, S., Senapin, S., Sithigorngul, P., and Chaivisuthangkura, P. (2014). Molecular cloning and characterization of a Toll receptor gene from Macrobrachium rosenbergii. Fish Shellfish Immunol. 36, 552-562. doi: 10.1016/ j.fsi.2013.12.025

Suraprasit, S., Methatham, T., Jaree, P., Phiwsaiya, K., Senapin, S., Hirono, I., et al. (2014). Anti-lipopolysaccharide factor isoform 3 from Penaeus monodon (ALFPm3) exhibits antiviral activity by interacting with WSSV structural proteins. Antiviral Res. 110, 142-150.

Tenor, J. L., and Aballay, A. (2008). A conserved Toll-like receptor is required for Caenorhabditis elegans innate immunity. EMBO Rep. 9, 103-109.

Tharntada, S., Ponprateep, S., Somboonwiwat, K., Liu, H., Söderhöll, I., Söderhöll, K., et al. (2009). Role of anti-lipopolysaccharide factor from the black tiger shrimp, Penaeus monodon, in protection from white spot syndrome virus infection. J. Gen. Virol. 90, 1491-1498. doi: 10.1099/vir.0.009621-0

Uematsu, S., and Akira, S. (2006). Toll-like receptors and innate immunity. J. Mol. Med. 84, 712-725.

Valanne, S., Wang, J. H., and Ramet, M. (2011). The Drosophila Toll signaling pathway. J. Immunol. 186, 649-656. doi: 10.4049/jimmunol.1002302

Wang, P. H., Liang, J. P., Gu, Z. H., Wan, D. H., Weng, S. P., and Yu, X. Q. (2012). Molecular cloning, characterization and expression analysis of two novel Tolls (LvToll2 and LvToll3) and three putative Spatzle-like Toll ligands (LvSpz1-3) from Litopenaeus vannamei. Dev. Comp. Immunol. 36, 359-371. doi: 10.1016/j.dci.2011.07.007

Wang, Z., Chen, Y. H., Dai, Y. J., Tan, J. M., Huang, Y., and Lan, J. F. (2015). A novel vertebrates Toll-like receptor counterpart regulating the antimicrobial peptides expression in the freshwater crayfish, Procambarus clarkii. Fish Shellfish Immunol. 43, 219-229. doi: 10.1016/j.fsi.2014.12.038

Werling, D., Jann, O. C., Offord, V., Glass, E. J., and Coffey, T. J. (2009). Variation matters: TLR structure and species-specific pathogen recognition. Trends Immunol. 30, 124-130. doi: 10.1016/j.it.2008.12.001

Yang, C., Zhang, J., Li, F., Ma, H., Zhang, Q., and Jose, P. T. (2008). A Toll receptor from Chinese shrimp Fenneropenaeus chinensis is responsive to Vibrio anguillarum infection. Fish Shellfish Immunol. 24, 564-574. doi: 10.1016/j.fsi. 2007.12.012

Yu, A. Q., Jin, X. K., Guo, X. N., Li, S., Wu, M. H., and Li, W. W. (2013). Two novel Toll genes (EsToll1 and EsToll2) from Eriocheir sinensis are differentially induced by lipopolysaccharide, peptidoglycan and zymosan. Fish Shellfish Immunol. 35, 1282-1292. doi: 10.1016/j.fsi.2013.07.044

Zhou, S. M., Yuan, X. M., Liu, S., Li, M., Tao, Z., and Wang, G. L. (2015). Three novel Toll genes (PtToll1-3) identified from a marine crab, Portunus trituberculatus: different tissue expression and response to pathogens. Fish Shellfish Immunol. 46, 737-744. doi: 10.1016/j.fsi.2015.07.027

Conflict of Interest Statement: The authors declare that the research was conducted in the absence of any commercial or financial relationships that could be construed as a potential conflict of interest.

Copyright (c) 2018 Huang, Chen, Hui and Ren. This is an open-access article distributed under the terms of the Creative Commons Attribution License (CC BY). The use, distribution or reproduction in other forums is permitted, provided the original author(s) and the copyright owner(s) are credited and that the original publication in this journal is cited, in accordance with accepted academic practice. No use, distribution or reproduction is permitted which does not comply with these terms. 